\title{
中共の核実験による牛乳の放射性ヨウ素の濃度 \\ The Contamination of Radioiodine in Milk Caused by Nuclear \\ Bomb Tests by Red China
}

(昭 和 42 年 6 月 15 日 受 理)

\section{三橋 俊 彦 檀 原宏}

(Toshihiko Mitsuhashi) (Hiroshi Danbara)

The concentration of radioiodine ( $\mathrm{I}-131)$ in milk in Japan was determined daily after explosion in five nuclear bomb tests by the Red China.

As the result:

1) The contamination of milk by radioiodine was detected very clearly and rapidly.

2) The maximum concentration of radioiodine in milk in Chiba was elevated to $400 \mathrm{pCi} / l$ in the first test, and the radioactive contamination continued during the period of about one month.

3) In the cases of the second to the fifth tests, the increase of radioiodine in milk was relatively low, and the activity disappeared within $7 \sim 10$ days after each explosion.

緒 言

中共はこれまでに 5 回核実験を行なっている。 中国本土で核爆発が行なわれた場合, 我国は地理的に 函めて近く，また気流の関係からも，それが我国に及は す影箁はかなり大きいと予湘される。

著者らは, 現在, 牛乳の放射性核種（主にSr-90, Cs137）を毎月，経常的に分析している。が，特に中共の 実験時には，その影響を重視して特別な測定体制をと り，牛乳に顕著に現われる，放射性ヨウ素（主としてI -131）の濃度を毎日測定し，その変化を観察した。

\section{分析方 法}

I-131 は 8 日の半減期をるち，核分裂物質 (Fission products）中に初期にはかなり多く含まれ（48時間後に は全放射能の䄪 $1 \%)$, 飼料から牛乳への移行の大きい放 射性核種である。したがって牛乳の放射能污染濃度を， 迅速に捕捉する最る有力な指標にあげられている。

放射性ヨウ素の分析は，大桃らの方法によった。（第 1 因)

これは, 乳清中の放射性ヨウ素の分析法で, 蛋白質に 結合した I-131 は測定できないが，極めて迅速簡易に測 定できる利点がある。そしてまた牛乳中では，この種の 形態のすのはかなり少なく, 実腙にこの値をすって全放 射性ヨウ素の量をあらわしても，さほど大きな誤差は招
第 1 因 牛乳中の放射性ヨウ素の分離測定

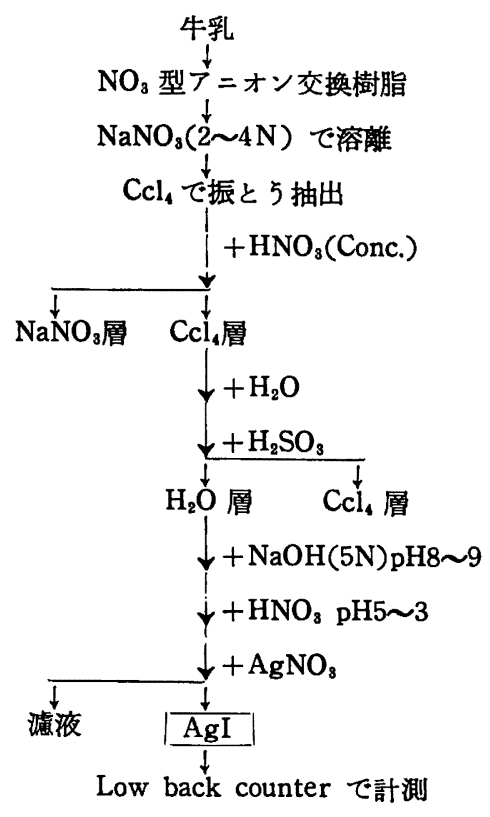

かないであろう。

試 料

試料は，核実験の翌日より，毎日，あるいは数日おき に採取した。採取地点は, 札幌, 新潟, 千菜, 鳥取およ 
び能本でこれらからそのつど適当な䇠所を選び，とく にその時期の青草（污染の多い）を給与している乳牛か ら推乳した。

$$
\text { 結果 }
$$

1）第 1 回目（昭和39年10月）の千莱の牛乳は，爆発 第 2 図第 1 回目核実験後の牛乳中の ${ }^{181}$ I 浱度

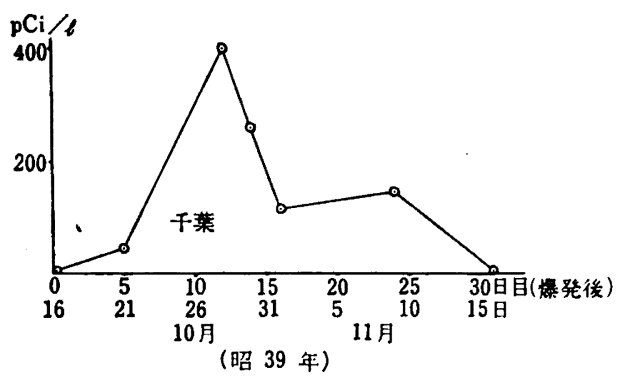

後12日目にピークが現われ， $400 \mathrm{pCi} / l$ とかなり高い值 を現わしたが，14日目には減少し始め，その污染は約 1 カ月間継続した。（第 2 図）

2）第 2 回目 (40年 5 月) 千葉の牛乳では, 前回上り る2 日早く, 10日後にピークとなり, その値も $125 \mathrm{pCi}$ $/ l$ とだいぶ低い值が出た。污染は約半月ほど続いた。

(第 3 図)

第 3 図 第 2 回目核実験後の牛乳中の ${ }^{131} 1$ 濃度

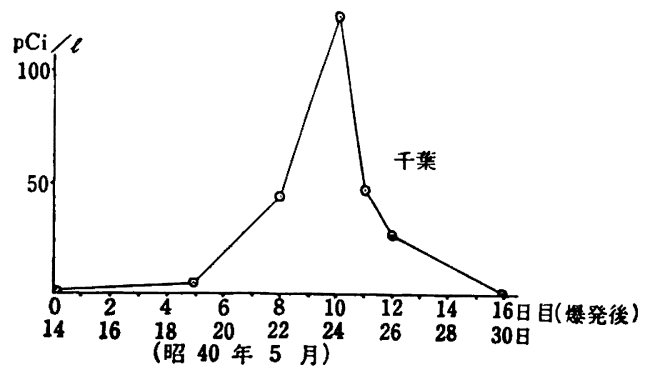

E3) 第 3 回目（41年 5 月）のときは, 札幌, 新渴, 鳥 取からす試料か得られた。

上このときは，ピークが異常に早く2 日目に現われ，そ の値も前の 2 回に比べてかなり低く, $42 \mathrm{pCi} / l$ であっ た。

気象関係，土壤，作物の方面では，聂日本の新潟，鳥 取に高い放射能が現われているが，今回の牛乳ではそれ が見られなかった。これはこの地域では，採取時にすで にピークを過ぎていたと考えられる。（第 4 图）

4）第 4 回目は都合により分析は行なわなかった。 第 5 回目（41年12月）の札幌，千菜，熊本における測
第 4 因 第 3 回目核実験後の牛乳中の ${ }^{181}$ I 濃度

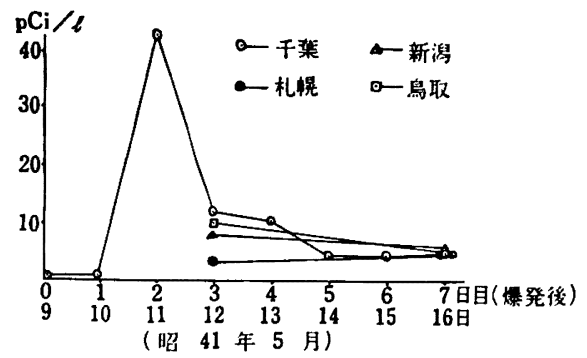

定結果は，千葉では 4 日目にピークが現われ，5 日目か ら急激に减少した。そのピークは $275 \mathrm{pCi} / l$ であった。 札幌の牛乳は， 4 日目に $210 \mathrm{pCi} / l, 8$ 日目に $75 \mathrm{pCi} / l$ に下がっている。この減衰のしかたから，4 日以前にそ のピークがあったに相違なく，それも或いは千葉以上の 値であったかとも想像される。

千葉の例からす明らかな通り，牛乳中のI-131の婊度は 核爆発直後は低く，数日後にピークが現われ，以後減少 する。しかし札幌の例ではそれが見られず，4 日目にい きなり高い濃度が現われ，8日目に急減している。

千葉, 札幌の例に反して熊本では，ほとんどその影響 がみられなかった。（第 5 図）

第 5 図 第 5 回目核実験後の牛乳中の ${ }^{181} I$ 濃度

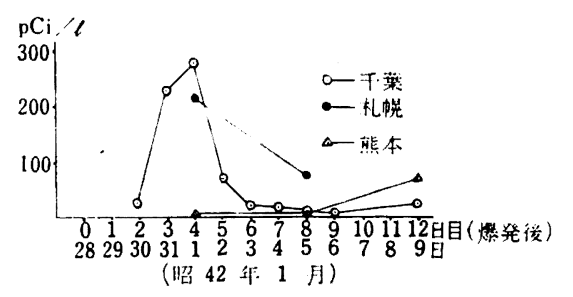

\section{考察および結論}

核実験による, 放射性ヨウ素の牛乳への影響は, 極め て明りょうに現われるが, その漕度は, 実験の規模, 気 象条件，飼料の給与量などによって，大いに異なるであ ろらと考えられる。例えば，ピークの出た時期，大きさ から，第 1 回目の実験は割合大規模で，核分裂物質がか なり上空 (成㸴圈) まで吹き上げられたと考えられ，そ の反面, 3 回目などはかなり小規模であったと想像され る。

以上のことから,

1）核実験が割合大規模の場合では，放射性ヨウ素は 牛乳に 5 日目ぐらいから影留が出始め, 10日過ぎ頃ピー クとなり,その後徐々汪減衰してゆく。

2）小規模な場合だと，放射性物質は成層圈まで達せ ず，比較的早く地上に降下して牛の飼料を污染するの 


\section{栄養と食粗}

で,そのピークが割合早く現われる。そしてさらに冬型 の気圧配置などに乗ると、ピークの出現は一層早くなる であろう。

放射性ヨウ素の濃度は, 核分裂物質の降下量の一応の 目安となるので, その濃度如何によっては, 牛乳で特に 問題とされている，Sr-90および，Cs-137 の濃度にす， 或いは注目せねばならなくなるであろう。

\section{要 約}

これまで 5 回行なわれた中共の核実験による，牛乳の 放射性ヨウ贵（I-131）の污染濃度を, 爆発の翌日から 毎日測定した。その結果，

1）中共の核実験により, 我国の牛乳に放射性ヨウ素 が，極めて明りょうに，かつ速やかに現われた。

2）その濃度, 最高値の現われる時間は, 核実験の規 模などで異なるが，第 1 回目で千葉の牛乳では最高 400
$\mathrm{pCi} / l$ が記録され，污染は 1 力月ほど続いた。

3）第 2 回以降には，あまり大きな淡度が検出され ず, 7 〜0日間で污染は消失した。

この調查研究には, 放射線医学総合研の大桃博士よ り，放射性ヨウ素の分析につき多大の御教示を また, 試料の採取は, 北海道農試畜産部, 九州農試畜産 部および新潟県の牫員の御協力により行なわれた。上記 の方々に対し心から感謝の意を表する次第である。

\section{文}

献

放射線審議会放射能测定部会：

放射性 $\exists$ ウ素分析法，(1965年 5 月）

農林水産技術会議事務局：

昭和41年度農林省関係放射能調查研究速報, (昭和 42 年 2 月)

（農林省畜産試験場）

\section{牛脂またはコーン油を摂取した雄・睢シロネズミにおける コレステロールおよひ総脂質の合成について}

離乳シロネズミの雄・雌をそれぞれ6群に分け，次 の 3 種の飼料を 9 または15週間（12または18週令まで）

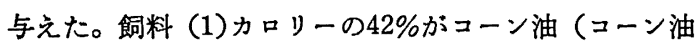
飼料), 飼料(2) カロリーの $40 \%$ が牛脂, $2 \%$ ガコーン

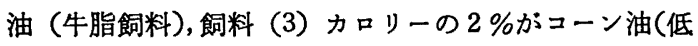
脂肪飼料)。所定の期間飼料給与後, 体重 $100 \mathrm{~g}$ 当り $6 \mu \mathrm{c}$ の $\mathrm{Na}-1-{ }^{14} \mathrm{C}$-アセテート $(2.0 \mathrm{mc} / \mathrm{mM})$ を腹膑内に注射 し，4時間のちに殺して，血漿および肝臓の脂質への "4Cーアセテートのとりこみならびに血漿, 肝臓, 屠体中 の脂質量を測定した。非コレステロール性脂 質の合成

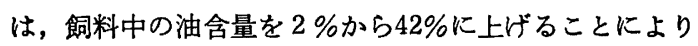
阻止され, これは性, 週令, 飼料中の油の種類には関係
ない。これに対し，コレステロールの合成は, 性, 週令, 油の種類に大きく左右された。低脂肪飼料ネズミのコレ ステロール合成量を 1 として表わすと，12週令では，二 ーン油飼料の雄ネズミ29, 雌ネズミ22, 牛脂飼料の雄ネ ズミ2.6, 倠ネズミ3.4。18週令ではコーン油飼料の雄ネ ズミ7.3, 倠ネズミ9.1, 牛脂飼料の雄ネズミ1.2, 倠ネズミ 3.7 であった。(図 1, 表 4)

Synthesis of Cholesterol and Total Lipid by Male and Female Rats Fed Beef Tallow or Corn Oil.

by Dupont J. : Lipid, 1, (6), 409〜414 (1967) (堀井) 